\title{
Normative Power Europe and in Field of Human Rights: is the EU a Force for Good in the World?"
}

\author{
RAJ A NOUREDDINE \\ The University of Melbourne, Australia \\ raja.noureddine@gmail.com
}

\begin{abstract}
Ian Manners (2002) famously argued that the European Union (EU) is a 'normative' power. According to this description, ethical values are fundamental both to the legal basis, and to the dayto-day policies of the EU. This essay evaluates the claim that the EU is a Normative Power, focusing on the field of human rights. Certainly, the EU strongly promotes its human rights policies as being a force for good in the world. The EU's has traditionally been supportive of international legal regimes, and its human rights values have conditioned its relations with other actors. Despite this, the EU's policies have often failed to change the behaviour of other actors. The main cause of this gap between rhetoric and reality is the conflict between the traditional realist interests of member states, and the ideals of the EU. The EU must be more conscious of this clash, if its human rights policies are to be successful.
\end{abstract}

Keywords: European Union, Normative Power, Human Rights, Milieu Shaping, International Law

Scholars have devoted considerable effort to understanding the European Union's (EU) role in international politics. It has been argued that the EU's global role can be understood as 'civilian', 'responsible', ${ }^{2}$ 'ethical', ${ }^{3}$ or 'small'. ${ }^{4}$ This essay will focus on the notion of the EU as a 'normative' power, first popularised by Ian Manners. ${ }^{5}$ Manners argued that the EU's ability to influence the behaviour of others by exporting its values, rendered it a distinct kind of actor in world politics. In this essay, I will investigate the EU's ability to influence the values and behaviour of nonmember states that are not tabled for accession. I will focus this analysis on the norm of human rights. Within this field, the EU vehemently promotes its policies as being a force for good in the world. ${ }^{6}$ I will argue that while the EU's rhetoric and some of its behaviour may indicate that it is a normative actor, many of its policies fail to create change, and its application of its norms is inconsistent. Thus, in spite of the EU's self-identification as a normative actor, its ability to use norms to influence the

\footnotetext{
${ }^{1}$ Duchêne, F. 1973. Europe's Role in World Peace. In: Mayne, R. (ed.) Europe Tomorrow: 16 Europeans Look Ahead. London, U.K.: Fontana

${ }^{2}$ Mayer, H. 2008. Is it still called 'Chinese Whispers'? The EU's rhetoric and action as a responsible global institution. International Affairs, 84, 62-79

${ }^{3}$ Aggestam, L. 2008. Introduction: ethical power Europe? International Affairs, 84, 1-11.

${ }^{4}$ Toje, A 2011, The European Union as a Small Power, J ournal of Common Market Studies, 49, 43-60

${ }^{5}$ Manners, I. 2002. Normative Power Europe: A Contradiction in Terms? J CMS: J ournal of Common Market Studies, 40, 235-258

${ }^{6}$ Aggestam 2008, p. 1
} 
behaviour of other states is severely limited. This essay is divided into three parts. In the first section, I will outline Ian Manners' original argument, as well as his distinction between the EU's normative identity, and its normative influence. In the second section, I will argue that the EU self-identifies as a normative actor and has on occasion pursued normative external policies. In the third section I will argue that despite this, the EU's values-based policies have not had a significant impact on the behaviour of other actors, and have been highly inconsistent. I will argue that the root cause of the EU's failure to be a normative actor is the unresolved tension between Member States' interests, and EU norms. Acknowledging the gap between the EU's identity and its ability to actually cause change represents an important step in realising its potential to be a force for good in international politics.

\section{The Concept of Normative Power}

In understanding normative power, Ian Manners' 2002 article on the subject is cited almost universally. The first aspect of Manners' argument pertains to the kind of actor which the EU is. Manners argues that the EU represents a new and distinct kind of actor within the international system, and transcends the anarchic and selfinterested behaviour of states. ${ }^{7}$ The EU's constitution as an "elite-driven, treaty based, legal order," means that its identity and behaviour are fundamentally based upon a set of common values. ${ }^{8}$ The most significant of these values are: peace, liberty, the rule of law, democracy, human rights, social solidarity, anti-discrimination, sustainable development, and good governance. ${ }^{9}$ These norms differentiate the EU from traditional state actors who act according to a realist and neo-realist paradigm in which security-related concerns outweigh ethical ones. ${ }^{10}$ Hence, Manners argues that the EU's norms provide it with a fundamentally different identity to other actors within the international system.

The second aspect of Manners' argument pertains to the kind of influence which the EU has within world politics. The EU's constitution on a normative basis "predisposes it to act normatively in world politics". ${ }^{11}$ According to this view, the EU is a force for good within world politics, and enacts a foreign policy aimed at promoting its nine core ethical norms. ${ }^{12}$ Manners ${ }^{13}$ argues that the EU's ability to exert such influence is both intrinsic and extrinsic, that is, the EU influences others both through its policies, and through Member States role modelling its values. Thus Manners claims that the EU has a capacity to "shape conceptions of 'normal' in international relations". ${ }^{14}$ It is this notion of influencing others by directly and indirectly spreading its values, which characterises the notion of the EU as a normative power.

\section{The Role of Norms in the EU's I dentity and its Global Role}

\footnotetext{
${ }^{7}$ Manners 2002, p. 240

${ }^{8}$ Manners 2002, p. 241

${ }^{9}$ Ibid.; Manners 2008

${ }^{10}$ Hyde-Price, A. 2008. A 'tragic actor'? A realist perspective on 'ethical power Europe'. International Affairs, 84, 29-44, p. 30

${ }^{11}$ Manners 2002, p. 252

${ }^{12}$ Aggestam 2008, p. 1

13 Manners 2002, p. 252

${ }^{14}$ Ibid., p. 239
} 
Manners' argument that the EU possesses a normative identity is reflected in the rhetoric of EU representatives and leaders. Certainly, this is insufficient to make the EU a normative actor; however, it provides some evidence to support Manners' ${ }^{15}$ assertion that the EU's values form the core of its identity. In 2012, Catherine Ashton, the High Representative for Foreign Affairs at the time, stated that human rights are "a silver thread that runs through everything we do in external relations". ${ }^{16}$ More generally, J urado observes that speeches from EU representatives imply that the EU's approach towards human rights abroad is drawn from its identity as a "community of values" ${ }^{17}$ Academics also tend to agree that national and EU leaders view the Union as a force for good in the international system. ${ }^{18}$ Finally, the EU's values play a key role in its underpinning legal documents. ${ }^{19}$ Human rights are explicitly referenced in the Maastricht Treaty, the Treaty of Amsterdam, The Treaty of Lisbon, and the European Security Strategy. These documents, as well as the discursive practices of EU representatives, lend support to Manners' argument that the Union possesses a normative identity.

Elements of the Union's human rights policies provide support for the view that the EU's external relations aim at shaping the international milieu to reflect its core norms. Smith identifies a number of mechanisms through which the EU disperses its norms, including the use of positive and negative conditionality in its agreements with third parties, the provision of development assistance, and the use of diplomatic means such as bilateral dialogues. ${ }^{20}$ The Union's use of these tools suggest an intention to be an international norms-promoter. Lee describes the EU's engagement with the North Korean government as an example of its norm-exporting behaviour. ${ }^{21}$ In their engagement with North Korea, the majority of actors remained firmly within a realist, strategic paradigm, being interested only in issues of "hard politics," and in particular, North Korea's nuclear weapons program. ${ }^{22}$ By contrast, the EU held a number of meetings with the North Korean government to voice its concern over the state of human rights in that country. ${ }^{23}$ This suggests that the Union's approach to world politics is not conditioned only by the traditional security-focused paradigm, but also by its ethical values. The EU's dialogue with North Korea signals an intention to engage with other actors not only within the traditional strategic paradigm which is mainly restricted to trade and defence, but also, on the level of ethical values. These efforts to cause other actors to adopt its values lens support for the view that the EU's international role is primarily normative.

\footnotetext{
${ }^{15}$ Ibid., p. 252

${ }^{16}$ Council of The European Union 2012, EU adopts Strategic Framework on Human Rights and Democracy, Luxembourg

${ }^{17} \mathrm{~J}$ urado, E. 2006. Assigning Duties in the Global System of Human Rights: The Role of the European Union. In:

Mayer, H. \& Vogt, H. (eds.) A Responsible Europe? Ethical Foundations of EU External Affairs. London: Palgrave Macmillan UK, p. 121

${ }^{18}$ Aggestam 2008, p. 1; Hyde-Price 2008, p. 29; Sjursen, H. 2006. The EU as a 'normative' power: how can this be? J ournal of European Public Policy, 13, 235-251, p. 236

${ }^{19}$ Whitman, RG 2011, Normative Power Europe: Empirical and Theoretical Perspectives, Basingstoke: Palgrave Macmillan, 2011, p. 2

${ }^{20}$ Smith, K. 2001. The EU, human rights and relations with third countries: 'foreign policy' with an ethical dimension? In: Smith, K. \& Light, M. (eds.) Ethics and Foreign Policy. Cambridge University Press, p. 188

${ }^{21}$ Lee, M. 2012. A step as normative power: the EU's human rights policy towards North Korea. Asia Europe

Journal, 10, 41-56, pp. 49-51

${ }^{22}$ Ibid., p. 49

${ }^{23}$ Ibid., pp. 49-51
} 
The EU's normative approach to world politics is particularly apparent in its support for international law. International legal regimes which bind states and state leaders to criminal and human rights norms have been seen as key tests of a normative actor. ${ }^{24}$ This is because such regimes are based on agreement and reciprocity between states, minimising the potential for traditional powers to impose their norms coercively or arbitrarily. ${ }^{25}$ Support of international law therefore allows for a distinction between normative actors, and traditional actors who merely use norms as a cloak for their own interests. The EU's normative stance towards its external relations has been reflected in its consistent support for international legal regimes. ${ }^{26}$ A key example of this was the EU's policy of encouraging African states to join the International Criminal Court (ICC), created in order to prosecute perpetrators of war crimes, and crimes against humanity. ${ }^{27}$ After promotion of the Court was adopted as an explicit aim of the EU's Common Foreign and Security Policy (CFSP) in 1998, the EU worked to persuade African nations to ratify and implement the ICC Statute. ${ }^{28}$ Furthermore, legal assistance and expertise was provided to those African states who ratified the Statute, in order to assist them with the implementation process. ${ }^{29}$ By not only supporting international legal regimes, but also actively assisting in their implementation, it would seem the EU hopes to embed its norms in world politics and create consequences for those who transgress these values. This suggests a commitment to promoting its values internationally, and lends support to the notion that the EU's role in international politics is distinctly normative.

\section{Limitations on the EU's Normative I nfluence}

These norms-based policies, as well as the EU's self-presentation as values-based actor, have created high expectations that the Union can be a force for good. ${ }^{30}$ However, overall, the EU's external policies have failed to cause third states to adopt its norms. Diez notes that an actor only possesses normative power in the fullest sense when an actor "A ... [is able] to make B do what she would otherwise not have done". ${ }^{31}$ The EU's ability to exert such tangible influence is limited. The most significant limitation on the EU's normative power is the tension between the EU's ethical norms, and the material interests of Member States. In their external relations, Member States have consistently prioritised their economic interests at the expense of the EU's ethical norms. This clash undermines the EU's ability to influence the behaviour of other actors in four ways: by rendering it unable to impose costs on non-compliance with its norms, by reducing the effectiveness of capacitybuilding programs, by leading to inconsistency in the application of its norms, and by damaging the Union's international reputation as a values-based actor.

Member States have been unwilling to use negative conditionality in order to enforce the EU's norms, when such measures conflict with their economic interests. This renders human rights conditionality ineffective. From a rationalist perspective,

\footnotetext{
${ }^{24}$ Sjursen 2006, p. 244; Barbé, E. \&J ohansson-Nogués, E. 2008. The EU as a modest 'force for good': the European Neighbourhood Policy. International Affairs, 84, 81-96, p. 81.

${ }^{25}$ Sjursen 2006, p. 244

26 Toje 2011, p. 254

${ }^{27}$ Scheipers, S. \& Sicurelli, D. 2008. Empowering Africa. J ournal of European Public Policy, 15, 607-623, p. 611

28 Ibid., p. 611

${ }^{29}$ Ibid., p. 611

30 Mayer 2008

${ }^{31}$ Diez, T. 2005. Constructing the Self and Changing Others: Reconsidering 'Normative Power Europe'.

Millennium - J ournal of International Studies, 33, 613-636, p. 616
} 
states are likely to abuse human rights when the material and political costs of noncompliance are low. ${ }^{32}$ Therefore, in order to cause other actors to adopt its norms, the EU and Member States must impose a high cost on external states who violate EU values. However, Member States have not placed a sufficiently high cost noncompliance. A key example of this has been the Member States' approach to the Code of Conduct on Arms Exports. In 1998, the EU adopted the Code, which required Member States to restrict arms transfers to third states where there was a risk of the weapons being used for internal repression. ${ }^{33}$ Erickson notes that by denying access to weapons to human-rights abusing regimes, the EU reduces their ability to oppress the population. ${ }^{34}$ However, in direct contrast to this intention, Member States have sold weapons to foreign governments irrespective of their transgression of EU norms. In fact, a positive correlation exists between human rights violations, and arms shipments from the EU. ${ }^{35}$ This suggests that Member States' arms exports are driven primarily by demand, rather than common EU policy. Consequently, the Code has not reduced the ability of human rights abusers to repress populations. While the Union may enact policies with normative goals, the effectiveness of these policies is reliant on Member States' actions. Disunity acts a significant limitation on the EU's ability export its norms.

Furthermore, even positive approaches to human rights such as capacity building programs, have been used to advance the economic interests of Member States. Youngs argues that within the boundaries imposed by the EU's norms, Member States continue to pursue traditional interests. ${ }^{36}$ While this may be understandable, it limits effectiveness of norms-based development programs. This has been prominent in the case of the Member States' relationships with China. Balducci describes how Member States have used human rights projects within China primarily as vehicles to strengthen their trading relationships. ${ }^{37}$ In the early 2000s, Germany developed a number of programs to strengthen China's legal system and judiciary. However, these projects ignored the sector of human rights, and instead, focused on streamlining China's commercial and business law to facilitate easier trade with German companies. $^{38}$ The United Kingdom and France similarly neglected normative projects by either focusing their development programs on commercial sectors or allocating smaller sums to human rights projects. ${ }^{39}$ While it seems predictable that Member States should pursue their economic interests, they have failed to resolve the tension between those interests, and the EU's norms. Convergence between interests and norms has not been achieved, with the former being pursued to the detriment of the latter. The tendency of Member States' economic interests to be prioritised at the expense of the EU's norms and common strategies, significantly limits the ability of the Union to have an impact on the behaviour of other actors internationally.

\footnotetext{
${ }^{32}$ Cardenas, S. 2004. Norm Collision: Explaining the Effects of International Human Rights Pressure on State Behavior. International Studies Review, 6, 213-232, p. 220

${ }^{33}$ Erickson, J . L. 2011. Market Imperative Meets Normative Power: Human Rights and European Arms Transfer

Policy. European J ournal of International Relations, 19, 209-234, p. 214

${ }^{34}$ Ibid., p. 214

${ }^{35}$ Ibid., p. 218

${ }^{36}$ Youngs, R. 2004. Normative Dynamics and Strategic Interests in the EU's External Identity. J CMS: J ournal of Common Market Studies, 42, 415-435, p. 422

${ }^{37}$ Balducci, G. 2010. The Limits of Normative Power Europe in Asia: The Case of Human Rights in China. East

Asia, 27, 35-55, p. 51

${ }^{38}$ Ibid., p. 51

${ }^{39}$ Balducci 2010, pp. 51-52
} 
The EU's inability to resolve the clash between the interests of Member States and the ethical values promoted in its rhetoric, may have a detrimental impact on its international reputation. Such a diminishment in the EU's reputation reduces its ability to export human rights norms. From an institutionalist perspective, states are more likely to violate norms when the reputational benefits of compliance are low, or international norms are unclear. ${ }^{40}$ Similarly, in order for states to adopt norms, domestic audiences must identify with them and view them as legitimate. ${ }^{41}$ Hence, the willingness of third parties to accept the EU's norms is to a certain extent reliant on it maintaining an image of fairness, as well as consistency between its valuesladen rhetoric, and its behaviour. The EU has failed to meet this standard, both undermining its self-identity as a normative actor, and reducing its ability to effectively export its values.

The EU's claims to be a normative actor internationally are undermined by its inconsistent application of its norms in its external relations. The EU and the Member States have tended to apply their collective norms less stringently in relation to third countries with which the Member States have important economic relationships. Mayer argues that the EU tends to be more demanding of human rights clauses, and more stringent in their enforcement, in its trade agreements with African, Carribean, and Pacific countries. ${ }^{42}$ By contrast, human rights conditionality is less emphasised in the EU's relationship with Asia. Similarly, the EU has been highly inconsistent in its approach to sponsoring UN Commission on Human Rights (UNCHR) resolutions which are critical of human rights abusers. The EU ceased to propose resolutions critical of China in 1996. This change was catalysed in the main by Germany and France, whose trade relationships with China were at the time beginning to grow. ${ }^{43} \mathrm{~A}$ regular human rights dialogue with China replaced these resolutions, however, the EU-China meetings have been labelled as no more than a means for the Chinese government to channel criticism of its human rights record into private fora. ${ }^{44}$ By contrast, the EU continued to sponsor resolutions critical of Zimbabwe until 2004, and of Sudan until at least $2007 .{ }^{45}$ Though realists may find such behaviour predictable where norms and interests conflict, ${ }^{46}$ it comes in direct contrast to the EU's rhetoric. In practice, economic interests play a greater role in the EU's external human rights policy than its self-identification as a normative actor, would suggest.

The mismatch between the EU's normative rhetoric and its practices have led many actors to take a negative view of its attempts to export its norms. Kinzelbach and Thelle argue that in relations between the EU and China, "the (false) premise that a negotiation and exchange between equal partners is taking place" belies the one-way nature of the exchange, which is resisted by the Chinese government. ${ }^{47}$ Similarly, Smith notes that in reaction to European intercession, Asian states have developed an

\footnotetext{
${ }^{40}$ Cardenas 2004, p. 220

41 Ibid., 2015

${ }^{42}$ Mayer 2008, p. 270

${ }^{43}$ Balducci 2010, p. 43

${ }^{44}$ Baker, P. 2002. Human Rights, Europe and the People's Republic of China. The China Quarterly, 45-63, p. 59

${ }^{45}$ Sicurelli, D. 2010. The European Union's Africa policies: norms, interests, and impact, Farnham, Surrey, England ; Burlington, VT : Ashgate Publishing, p. 40

${ }^{46}$ Hyde-Price 2008, p. 30

${ }^{47}$ Kinzelbach, K. \& Thelle, H. 2011. Taking Human Rights to China: An Assessment of the EU's Approach. The China Quarterly, 205, 60-79, p. 79
} 
“'Asian values' response to Western... 'universal' human rights”. ${ }^{48}$ This 'Asian values' response undermines the EU's universalist approach to human rights, and instead suggests that the EU's ethical values are little more than a form of cultural imperialism, thereby allowing Asian states to justify non-compliance with the EU's human rights norms. African nations have also resisted the intervention of the EU, as was the case in 2002 and 2004, when they joined with Asian nations at the UNCHR to block EU-sponsored resolutions condemning Zimbabwe. ${ }^{49}$ Hence, the EU's attempts to export its values have not always been well-received by third states. Though it may be impossible to know the root cause of resistance to EU norms, evidently the EU has been unsuccessful in creating a sufficient sense of legitimacy and consistency to convince other actors to adopt its values. The EU's selfaggrandizement as a force for good has created expectations of a consistently normative approach to world politics, which it has failed to meet. ${ }^{50}$ This failure to live up to its own rhetoric represents a double-standard which delegitimises the EU's identity as a non-traditional normative actor. By applying its human rights norms inconsistently, the EU sends the message that these norms are merely a tool to exert power over other actors. In doing so the EU, elicits the disaffection of other states, and significantly reduces the change-making power of its policies. Perhaps most importantly, the gap between expectations and reality creates resistance to the EU's values in precisely the regions which its policies target.

\section{Conclusion}

Helene Sjursen warns that conceptions of the EU as a normative power are so close to being exact reflections of the Union's own rhetoric that they "set the alarm bells ringing". ${ }^{51}$ Perhaps more concerning, as Mayer argues, is the fact that the EU's selfaggrandizing rhetoric has led to unrealistic expectations of what the it can achieve. ${ }^{52}$ Manners' notions of a norms-based actor with a norms-based foreign policy simply do not reflect the policies and practices of the EU and its Member States. This essay has shown that the EU and the Member States have not transcended interest-based politics in favour of common policies and ideas as was predicted by Manners. ${ }^{53}$ Indeed, Member States have consistently prioritised their own interests above the norms enshrined in the EU's rhetoric and policies. This both delegitimises the EU's role in international politics, and limits the effectiveness of its human rights policies. Thus, the inevitable conclusion is that the European Union is neither a normative actor, nor normatively powerful.

Nonetheless, polls show that Europeans want the EU to play a larger and more ethical role within world politics. ${ }^{54}$ In order to be more effective in exporting its norms, the EU must focus on creating a consensus between Member States about its international role. Erickson argues that despite the rhetoric of European leaders, the belief in "normative power is held neither widely nor deeply enough to consistently

\footnotetext{
${ }^{48}$ Smith, K. 2006. The Limits of Proactive Cosmopolitanism. In: Ole, E. \& Michael, S. (eds.) The European Union's Roles in International Politics. Routledge, p. 165

${ }^{49}$ Ibid., p. 165

${ }^{50}$ Mayer 2008, p. 77

${ }^{51}$ Sjursen 2006, p. 235

52 Mayer 2008, p. 77

${ }^{53}$ Manners 2002, p. 239

${ }^{54}$ Mayer 2008, p. 77
} 
shape member behaviour" ${ }^{55}$ In order to achieve this agreement, the EU must take a more realistic view of its role and capabilities in the international sphere. Hyde-Price argues that the EU must act as a "calculator not a crusader", ${ }^{56}$ by becoming more sensitive to the interests of Member States, and reducing the ideational aspects of its external policies. Thus, the EU should maintain its attention to human rights norms, but it should prioritise normative action in domains where Member States have shared interests, and be more conscious that where normative intentions conflict with economic or strategic realities, the latter are likely to prioritised by political actors. ${ }^{57}$ This seems to be wise advice. The EU's apparent unawareness of the clash between interests and norms has put its actions out of step with its rhetoric, and undermined its international image. By being conscious of the interests of Member States, the EU is more likely to create consensus about its normative role, and in turn, to execute that role effectively and consistently. The greatest challenge for the EU going forward, is to make its policy aspirations more realistic, without entirely sacrificing its normative outlook - which despite its flaws, remains an important character trait of the Union. Further research should investigate the extent of Member States' willingness to play a normative role, and how best to create agreement between them. In addition, research should articulate the specific regions and policy fields in which the EU can have the greatest normative impact. Such research will help the EU to realise its potential to be a force for good in world politics.

\footnotetext{
${ }^{55}$ Erickson 2011, p. 226

${ }^{56}$ Hyde-Price 2008, p. 29

57 Ibid., p. 29
} 